Article

\title{
Oil Content, Fatty Acid Composition and Distributions of Vitamin-E-Active Compounds of Some Fruit Seed Oils
}

\author{
Bertrand Matthäus ${ }^{1}$ and Mehmet Musa Özcan ${ }^{2, *}$ \\ 1 Max Rubner-Institut, Federal Research Institute for Nutrition and Food, Schützenberg 12, \\ 32756 Detmold, Germany; E-Mail: bertrand.matthaus@mri.bund.de \\ 2 Department of Food Engineering, Faculty of Agriculture, University of Selcuk, 42079 Konya, Turkey \\ * Author to whom correspondence should be addressed; E-Mail: mozcan@selcuk.edu.tr; \\ Tel.: +90-332-223-2933; Fax: +90-332-241-0108.
}

Academic Editor: Adrianne Bendich

Received: 10 September 2014 / Accepted: 21 January 2015 / Published: 29 January 2015

\begin{abstract}
Oil content, fatty acid composition and the distribution of vitamin-E-active compounds of selected Turkish seeds that are typically by-products of the food processing industries (linseed, apricot, pear, fennel, peanut, apple, cotton, quince and chufa), were determined. The oil content of the samples ranged from 16.9 to $53.4 \mathrm{~g} / 100 \mathrm{~g}$. The dominating fatty acids were oleic acid (apricot seed oil, peanut oil, and chufa seed oil) in the range of 52.5 to $68.4 \mathrm{~g} / 100 \mathrm{~g}$ and linoleic acid (pear seed oil, apple seed oil, cottonseed oil and quince seed oil) with 48.1 to $56.3 \mathrm{~g} / 100 \mathrm{~g}$, while in linseed oil mainly $\alpha$-linolenic acid $(53.2 \mathrm{~g} / 100 \mathrm{~g})$ and in fennel seed oil mainly $18: 1$ fatty acids $(80.5 \mathrm{~g} / 100 \mathrm{~g})$ with petroselinic acid predominating. The total content of vitamin-E-active compounds ranged from 20.1 (fennel seed oil) to $96 \mathrm{mg} / 100 \mathrm{~g}$ (apple seed oil). The predominant isomers were established as $\alpha$ - and $\gamma$-tocopherol.
\end{abstract}

Keywords: fruit seed; oil content; fatty acids; vitamin-E-active compounds; by-products; oil characterisation

\section{Introduction}

Large amounts of different seeds are discarded yearly as by-products of food processing [1,2]. These seeds are often rich sources of oil and other interesting minor compounds. Since some time an increasing interest in oils from unconventional seeds has been noted [3-5], and the by-products generated 
by fruit and vegetable industry may contribute as important sources for such oils. The added value of the by-products and the potential use of these resulting seed oils depends on the fatty acid composition and the content of minor components in the oil. It is desirable that the quantities of seeds which accumulate during fruit processing as residues from various fruits and vegetables are utilized as sources for the production of oils. The continued expansion in the food industry indeed calls attention to different fruit seeds as a potential source for oil. To ensure the utilization of these by-products more information about the oil content and the composition of different fruits is required showing the economical and efficient usability of these seeds [1,6]. The aim of the present study was to compare the oil contents as well as the composition of fatty acids and vitamin-E-active compounds of oils extracted from selected seeds.

\section{Material and Methods}

\subsection{Material}

The samples were collected by hand in May and August in 2007 from plants growing at several locations of Turkey. Seeds and kernels were obtained from fruits by hand-processing and then transferred to laboratory in polypropylene bags under cool conditions. Then they were stored in glass jars at $6^{\circ} \mathrm{C}$ until analysis. Detailed information related to the samples is given in Table 1.

Table 1. Seeds used in experiment.

\begin{tabular}{ccccc}
\hline Sample No. & General Name & Botanical Name & Family & Locations \\
\hline 1 & Linseed & Linum usitatissimum & FLinaceae & Akören-Konya \\
2 & Apricot (sweet) & Prunus armeniaca & Rosacea & Beybes-Konya \\
3 & Apricot (bitter) & Prunus armeniaca & Rosaceae & Beybes-Konya \\
4 & Pear & Pyrus communis & Rosaceae & Ankara \\
5 & Fennel (dulce) & Foeniculum vulgare & Apicaceae & Konya \\
6 & Peanut & Arachis hypogaea & Leguminaceae & Silifke-Mersin \\
7 & Apple (Golden) & Malus communis & Rosaceae & Eğridir-Isparta \\
8 & Apple (Starking) & Malus communis & Rosaceae & Hadim-Konya \\
9 & Cotton & Gossypium hirsutum & Malvaceae & Adana \\
10 & Quince & Cydonia vulgaris & Malvaceae & Beybes-Konya \\
11 & Chufa & Cyperus esculentus & Cyperaceae & Çumra-Konya \\
12 & Apple (Starking) & Malus communis & Rosaceae & Karaman \\
\hline
\end{tabular}

\subsection{Reagents}

Petroleum ether (40-60) was of analytical grade ( $>98 \%$; Merck, Darmstadt, Germany). Heptane and tert-butyl methyl ether were of HPLC grade (Merck, Darmstadt, Germany). Tocopherol and tocotrienol standard compounds were purchased from CalBiochem (Darmstadt, Germany). 


\subsection{Oil Content}

The oil content was determined according to the method ISO 659:1998 [7]. About $2 \mathrm{~g}$ of the seeds were ground in a ball mill and extracted with petroleum ether in a Twisselmann apparatus for $6 \mathrm{~h}$. The solvent was removed by a rotary evaporator at $40{ }^{\circ} \mathrm{C}$ and 25 Torr. The oil was dried by a stream of nitrogen and stored at $-20^{\circ} \mathrm{C}$ until use.

\subsection{Fatty Acid Composition}

The fatty acid composition was determined following the ISO standard ISO 5509:2000 [8]. In brief, one drop of the oil was dissolved in $1 \mathrm{~mL}$ of $n$-heptane, $50 \mu \mathrm{g}$ of sodium methylate (Merck, Darmstadt, Germany) was added, and the closed tube was agitated vigorously for $1 \mathrm{~min}$ at room temperature. After addition of $100 \mu \mathrm{L}$ of water, the tube was centrifuged at $4500 \mathrm{~g}$ for $10 \mathrm{~min}$ and the lower aqueous phase was removed. Then $50 \mu \mathrm{L}$ of $\mathrm{HCl}$ ( 1 mol with methyl orange (Merck, Darmstadt, Germany)) was added, the solution was shortly mixed, and the lower aqueous phase was rejected. About $20 \mathrm{mg}$ of sodium hydrogen sulphate (monohydrate, extra pure; Merck, Darmstadt, Germany) was added, and after centrifugation at $4500 \mathrm{~g}$ for $10 \mathrm{~min}$, the top $n$-heptane phase was transferred to a vial and injected in a HP5890 gas chromotograph (Agilent Technologies Sales \& Services GmbH \& Co. KG, Waldbronn, Germany), with a capillary column, CP-Sil $88(100 \mathrm{~m}$ long, $0.25 \mathrm{~mm} \mathrm{ID}$, film thickness $0.2 \mu \mathrm{m})$. The temperature program was as follows: From $155^{\circ} \mathrm{C}$; heated to $220^{\circ} \mathrm{C}\left(1.5^{\circ} \mathrm{C} / \mathrm{min}\right), 10 \mathrm{~min}$ isotherm; injector $250{ }^{\circ} \mathrm{C}$, detector $250{ }^{\circ} \mathrm{C}$; carrier gas $36 \mathrm{~cm} / \mathrm{s}$ hydrogen; split ratio 1:50; detector gas $30 \mathrm{~mL} / \mathrm{min}$ hydrogen; 300 $\mathrm{mL} / \mathrm{min}$ air and $30 \mathrm{~mL} / \mathrm{min}$ nitrogen; manual injection volume less than $1 \mu \mathrm{L}$. The peak areas were computed by the integration software, and percentages of fatty acid methyl esters (FAME) were obtained as weight percent by direct internal normalization.

\subsection{Vitamin-E-Active Compounds}

For determination of vitamin-E-active compounds, a solution of $250 \mathrm{mg}$ of oil in $25 \mathrm{~mL}$ of $n$-heptane was directly used for the HPLC. The HPLC analysis was conducted using a Merck-Hitachi low-pressure gradient system, fitted with a L-6000 pump (Merck-Hitachi, Darmstadt, Germany), a Merck-Hitachi F-1000 fluorescence spectrophotometer (Darmstadt, Germany; detector wavelengths for excitation $295 \mathrm{~nm}$, for emission $330 \mathrm{~nm}$ ), and a ChemStation integration system (Agilent Technologies Deutschland $\mathrm{GmbH}$, Böblingen, Germany). The samples in the amount of $20 \mu \mathrm{L}$ were injected by a Merck 655-A40 autosampler (Merck-Hitachi, Darmstadt, Germany) onto a Diol phase HPLC column $25 \mathrm{~cm} \times 4.6 \mathrm{~mm}$ ID (Merck, Darmstadt, Germany) used with a flow rate of $1.3 \mathrm{~mL} / \mathrm{min}$. The mobile phase used was $99 \mathrm{~mL}$ $n$-heptane $+1 \mathrm{~mL}$ tert-butyl methyl ether [9]. The mean values were given in the tables, without the standard deviation, because this value would represent only the deviation of the method and not the variation of the appropriate sample.

\section{Results and Discussion}

The results for oil content and fatty acid composition of the seeds are shown in Table 2 . The oil contents of the seeds were found between $16.9 \mathrm{~g} / 100 \mathrm{~g}(\mathrm{dw})$ (quince) and $53.6 \mathrm{~g} / 100 \mathrm{~g}$ (dw) (apricot seeds, sweet). While most of the samples showed oil contents below or near $30 \mathrm{~g} / 100 \mathrm{~g}$, the oil content of apricot 
seeds (sweet and bitter) was remarkably higher with showing values of $53.4 \mathrm{~g} / 100 \mathrm{~g}(\mathrm{dw})$ and $45.2 \mathrm{~g} / 100 \mathrm{~g}(\mathrm{dw})$, respectively. From an economical point of view, this high oil content would justify oil extraction of the seeds, whereas for seeds with oil contents below $20 \mathrm{~g} / 100 \mathrm{~g}$ an economical extraction of oil is only meaningful by solvent when the meal contains valuable protein, e.g., soybean or if the oil can be marketed as high-quality cold-pressed edible oil. The oil content of linseed was found relatively low in comparison to the literature with 34.2 to $44.4 \mathrm{~g} / 100 \mathrm{~g}$ [10], probably due to season, environment and locations.

Results for the fatty acid composition showed that the oils can be divided into two groups with one group predominant in 18:1 fatty acids and the other group high in linoleic acid (18:2). Only in linseed oil was $\alpha$-linolenic acid predominating with amounts of $53.2 \mathrm{~g} / 100 \mathrm{~g}$, while its content in the other samples was between 0.1 and $1.0 \mathrm{~g} / 100 \mathrm{~g}$, only. The highest contents of oleic acid were found in apricot (sweet) $(68.3 \mathrm{~g} / 100 \mathrm{~g})$, chufa $(62.4 \mathrm{~g} / 100 \mathrm{~g})$ and apricot (bitter) $(57.8 \mathrm{~g} / 100 \mathrm{~g})$ seed oils. Fennel (dulce) seed oil is characterized by a high content of $18: 1$ fatty acids $(80.5 \mathrm{~g} / 100 \mathrm{~g})$ with petroselinic acid as predominant fatty acid. The used GLC-method was not able to separate petroselinic acid from oleic acid, but from literature it is known that petroselinic acid is predominant in members of the family Apiaceae. From a nutritional point of view this high content of oleic acid favors these seed oils for human nutrition. The content of linoleic acid of the oils ranged from $12.0 \mathrm{~g} / 100 \mathrm{~g}$ (fennel seed oil) to $56.3 \mathrm{~g} / 100 \mathrm{~g}$ (cotton seed oil), with half (six) of the selected seed oils comprising of at least $50 \mathrm{~g} / 100 \mathrm{~g}$ linoleic acid. The relatively low content of saturated fatty acids such as palmitic acid or stearic acid with amounts below $10 \mathrm{~g} / 100 \mathrm{~g}$ is interesting from a nutritional point of view. Only chufa seed oil (17.2 g/100 g) and cottonseed oil $(24.2 \mathrm{~g} / 100 \mathrm{~g})$ had higher amounts of nutritionally unfavourable saturated fatty acids. The fatty acid composition found in the present investigation for apricot seed oil was similar to the fatty acid composition published by Dubois et al. [11] with $4.4 \mathrm{~g} / 100 \mathrm{~g}$ palmitic acid, $0.5 \mathrm{~g} / 100 \mathrm{~g}$ stearic acid, $66.3 \mathrm{~g} / 100 \mathrm{~g}$ oleic acid, and $28.6 \mathrm{~g} / 100 \mathrm{~g}$ linoleic acid.

The results from Dubois et al. [11] also confirm the presented results for chufa seed oil with $13.8 \mathrm{~g} / 100 \mathrm{~g}$ palmitic acid, $3.2 \mathrm{~g} / 100 \mathrm{~g}$ stearic acid, $72.6 \mathrm{~g} / 100 \mathrm{~g}$ oleic acid, and $8.9 \mathrm{~g} / 100 \mathrm{~g}$ linoleic acid. Similarly, Kim et al. [12] published the high amount of oleic acid $(65.5 \mathrm{~g} / 100 \mathrm{~g})$ and the moderate amounts of palmitic acid (15.2 g/100 g) and linoleic acid $(16.2 \mathrm{~g} / 100 \mathrm{~g})$ for chufa seed oil. A little different was the fatty acid composition for chufa seed oil reported by Eteshola and Oraedu [13] with $28.1 \mathrm{~g} / 100 \mathrm{~g}$ myristic acid, $14.5 \mathrm{~g} / 100 \mathrm{~g}$ palmitic acid, $3.4 \mathrm{~g} / 100 \mathrm{~g}$ stearic acid, $44.8 \mathrm{~g} / 100 \mathrm{~g}$ oleic acid and $8.8 \mathrm{~g} / 100 \mathrm{~g}$ linoleic acids. Especially the finding of myristic acid and the low amount of linoleic acid do not agree with the results from other authors or the presented work. Different varieties or locations of cultivation can be reasons for these differences.

Reiter et al. [14] determined $4.4 \mathrm{~g} / 100 \mathrm{~g}$ palmitic acid, $73.9 \mathrm{~g} / 100 \mathrm{~g}$ petroselinic, $4.8 \mathrm{~g} / 100 \mathrm{~g}$ oleic acid, and $16.3 \mathrm{~g} / 100 \mathrm{~g}$ linoleic acid in fennel seed oil. The amount of 18:1 fatty acids found in the present investigation was very similar to the results from Reiter et al. [14]. 
Table 2. Oil content and fatty acid composition of seed oils (g/100 g).

\begin{tabular}{|c|c|c|c|c|c|c|c|c|c|c|c|c|}
\hline & Oil & $16: 0$ & $16: 1-\delta-7$ & $16: 1-\delta-9$ & 18:0 & Sum 18:1 & $18: 1-\delta-9$ & $18: 1-\delta-11$ & $18: 2-\delta-9,12$ & $20: 1-\delta-11$ & $18: 3-\delta-9,12,15$ & $18: 4-\delta-6,9,12,15$ \\
\hline Linseed & 33.6 & 4.9 & n.d. & 0.1 & 4.8 & n.d. & 20.2 & 0.6 & 15.0 & 0.4 & 53.2 & n.d. \\
\hline Apricot (sweet) & 53.4 & 4.9 & n.d. & 0.6 & 1.1 & n.d. & 68.3 & 1.4 & 23.1 & 0.1 & 0.1 & 0.1 \\
\hline Apricot (bitter) & 45.2 & 6.4 & 1.0 & 0.9 & 1.0 & n.d. & 57.8 & 1.8 & 31.4 & 0.1 & 0.2 & 0.1 \\
\hline Pear (Ankara) & 31.7 & 9.0 & n.d. & 0.2 & 2.1 & n.d. & 31.8 & 0.5 & 53.6 & 1.2 & 0.4 & 0.4 \\
\hline Fennel (Dulce) & 18.2 & 4.3 & 0.2 & 0.2 & 1.6 & 80.5 & & & 12.0 & 0.3 & 0.4 & n.d. \\
\hline Peanut & 38.3 & 9.5 & n.d. & 0.1 & 3.2 & n.d. & 52.5 & n. d. & 28.3 & 1.5 & 0.1 & 1.0 \\
\hline Apple (Golden) & 21.9 & 7.0 & 0.1 & 0.1 & 1.9 & n.d. & 35.7 & 0.5 & 51.7 & 1.1 & 0.6 & 0.5 \\
\hline Apple (Starking) & 25.6 & 6.8 & 0.1 & 0.10 & 2.0 & n.d. & 40.4 & n. d. & 48.1 & 1.2 & 0.3 & 0.5 \\
\hline Cotton & 27.0 & 21.9 & n.d. & 0.5 & 2.3 & n.d. & 14.6 & 0.7 & 56.3 & 0.3 & 0.2 & 0.1 \\
\hline Quince & 16.9 & 6.8 & 0.1 & 0.2 & 1.5 & n.d. & 33.8 & 0.6 & 55.4 & 0.6 & 0.2 & 0.3 \\
\hline Chufa & 17.3 & 14.5 & n.d. & 0.1 & 2.7 & n.d. & 62.4 & 0.9 & 17.0 & 0.6 & 0.6 & 0.3 \\
\hline Apple (Starking) & 23.5 & 6.3 & 0.1 & 0.1 & 2.1 & n.d. & 38.8 & 0.3 & 49.6 & 1.3 & 0.3 & 0.5 \\
\hline
\end{tabular}

16:0, palmitic acid; $16: 1-\delta-7,7 \mathrm{c}$-hexadecenoic acid; 16:1- $\delta$-9, 9 c-hexadecenoic acid 18:0, stearic acid; Sum 18:1, 18:1- $\delta$-6 (petroselinic acid) + 18:1- $\delta-9$ (oleic acid) + 18:1- $\delta$-11 (cis-vaccenic acid); 18:1- $\delta$-9, oleic acid; 18:1- $\delta$-11, cis-vaccenic acid; 18:2- $\delta$-9,12, linoleic acid; 20:1- $\delta-11$, gondoic acid; 18:3- $\delta-9,12,15, \alpha-l i n o l e n i c$ aicd; $18: 4-\delta-6,9,12,15$, stearidonic acid; n.d., not detectable. 
In linseed oil, the major fatty acids were reported as $5.5 \pm 1.5 \mathrm{~g} / 100 \mathrm{~g}$ palmitic acid, $3.5 \pm 1.2 \mathrm{~g} / 100 \mathrm{~g}$ stearic acid, $22.1 \pm 5 \mathrm{~g} / 100 \mathrm{~g}$ oleic acid, $20.5 \pm 1.5 \mathrm{~g} / 100 \mathrm{~g}$ linoleic acid and $47.5 \pm 5.6 \mathrm{~g} / 100 \mathrm{~g} \alpha$-linolenic acid [15]. Also, Seher and Gundlach [16] established $6.7 \mathrm{~g} / 100 \mathrm{~g}$ palmitic acid, $3.42 \mathrm{~g} / 100 \mathrm{~g}$ stearic acid, $16.8 \mathrm{~g} / 100 \mathrm{~g}$ oleic acid, $16.5 \mathrm{~g} / 100 \mathrm{~g}$ linoleic acid and $54.7 \mathrm{~g} / 100 \mathrm{~g} \alpha$-linolenic acid in linseed oil. Other authors found 4.0-7.0 g/100 g palmitic acid, 2.0-4.0 g/100 g stearic acid, 14.0-38.0 g/100 g oleic acid, 7.0-19.0 g/100 g linoleic acid and 35.0-66.0 g/100 g $\alpha$-linolenic acid [17], while Overeem et al. [18] reported $5.3 \mathrm{~g} / 100 \mathrm{~g}$ palmitic acid, $3.1 \mathrm{~g} / 100 \mathrm{~g}$ stearic acid, $18.1 \mathrm{~g} / 100 \mathrm{~g}$ oleic acid, $15.2 \mathrm{~g} / 100 \mathrm{~g}$ linoleic acid and $54.10 \mathrm{~g} / 100 \mathrm{~g} \alpha$-linolenic acid in linseed oil. Ryan et al. [19] determined $6.6 \mathrm{~g} / 100 \mathrm{~g}$ palmitic acid, $4.1 \mathrm{~g} / 100 \mathrm{~g}$ stearic acid, $24.0 \mathrm{~g} / 100 \mathrm{~g}$ oleic acid, $19.90 \mathrm{~g} / 100 \mathrm{~g}$ linoleic acid and $43.3 \mathrm{~g} / 100 \mathrm{~g}$ $\alpha$-linolenic acids. Within a certain variation the published results agree with the results of the present paper considering linseed oil as an important source of polyunsaturated $\alpha$-linolenic acid with comparable low amounts of saturated fatty acids.

Palmitic acid and linoleic acid were the dominant fatty acids, constituting 70-80 g/100 g of the total fatty acids in the apple fruit [20]. As seen in Table 2, the fatty acid composition of apple seed oils in this investigation show similar results.

For peanut oil Dubois et al. [11] found $11.2-16.1 \mathrm{~g} / 100 \mathrm{~g}$ palmitic acid, 3.2-4.1 g/100 g stearic acid, 35.9-58.7 g/100 g oleic acid, 20.7-37.3 g/100 g linoleic acid and 1.2-1.7 g/100 g eicosanoic acid which is in the range observed in the presented results. Other authors reported 6.0-16.0 g/100 g palmitic acid, $1.3-6.5 \mathrm{~g} / 100 \mathrm{~g}$ stearic acid, 35.0-72.0 g/100 g oleic acid and 13.0-45.0 g/100 g linoleic acids for peanut oil [21].

In cottonseed oil, 21.0 and $27.2 \mathrm{~g} / 100 \mathrm{~g}$ palmitic acid, 1.8 and $2.2 \mathrm{~g} / 100 \mathrm{~g}$ stearic acid, 16.9 and $16.9 \mathrm{~g} / 100 \mathrm{~g}$ oleic acid, 50.5 and $56.7 \mathrm{~g} / 100 \mathrm{~g}$ linoleic acid and 0.9 and $1.2 \mathrm{~g} / 100 \mathrm{~g} \alpha$-linolenic acids were determined [16], statistically within the range observed in the current study. According to Yazıcıoğlu and Karaali [21] cottonseed oil contained 17.0-31.0 g/100 g palmitic acid, 13.0-44.0 g/100 g oleic acid and 33.0-59.0 g/100 g linoleic acids. Also, Dubois et al. [11] determined $24.2 \mathrm{~g} / 100 \mathrm{~g}$ palmitic acid, 2.3 $\mathrm{g} / 100 \mathrm{~g}$ stearic acid, $17.4 \mathrm{~g} / 100 \mathrm{~g}$ oleic acid and $53.2 \mathrm{~g} / 100 \mathrm{~g}$ linoleic acids in cottonseed oil.

In vegetable oils four different derivatives of tocopherols and tocotrienols $(\alpha-, \beta-, \gamma-, \delta$-), respectively, can be found as vitamin-E-active compounds differing in the methylation of the chroman ring. Vitamin-E-active compounds have two functions: On one side they stabilize the oil against oxidative deterioration during storage or heat-treatment and on the other side they have some biological effects to humans. The main biochemical function of the tocopherols is believed to be the protection of polyunsaturated fatty acids against peroxidation [22,23]. The biological effect is derived from the inhibitory effect of vitamin-E-active compounds on the oxidation of low-density lipoprotein which may be responsible for the formation of atherosclerotic plaque, one reason for myocardial infarction and cardiovascular death [24]. Whereas the antioxidant and the anti-inflammatory properties of $\alpha$-tocopherol have been well established, it is becoming increasingly evident that other isomers, especially $\gamma$-tocopherol are equally potent or possess additional biological properties [25,26]. Recent research has also shown that $\gamma$-tocopherol is a better negative risk factor for certain types of cancer and myocardial infarctions than $\alpha$-tocopherol, whereas a high supplementation of $\alpha$-tocopherol can deplete the body of $\gamma$-tocopherol [27].

In general the antioxidant activity increases for tocopherols and tocotrienols in the order $\alpha$ to $\delta$, whereas the biological activity is opposite to the antioxidant activity [28,29]. Another member of this class of compounds is plastochromanol-8 (P-8). Its structure is similar to that of $\gamma$-tocopherol, but its basic 
molecular structure is a chromanol-6 ring in which methyl groups are located at positions 2, 7 and 8 . The number of isoprene units on the side chain of position 2 is variable. Plastochromanol- 8 is described as being more effective against oxidative deteriorations than $\alpha$-tocopherol [30], while tocotrienols are less helpful in inhibiting autoxidation than tocopherols [31].

Due to the antioxidant properties the content and the composition of vitamin-E-active compounds is an important feature for the assessment of seed oils. The total content of vitamin-E-active compounds in the different seeds varied between 20.1 (fennel) and $94.0 \mathrm{mg} / 100 \mathrm{~g}$ (quince) (Table 3). In comparison, the total content of vitamin-E-active compounds in rapeseed oil ranges between 43 and $268.0 \mathrm{mg} / 100 \mathrm{~g}$ and in soybean oil between 60.0 and $337.0 \mathrm{mg} / 100 \mathrm{~g}$ [32].According to this, the contents of vitamin-E-active compounds in the different seed oils from fruits and vegetables could be a good source for antioxidants.

Table 3. Distribution of vitamin-E-active compounds of seed oils (mg/100 g).

\begin{tabular}{cccccccc}
\hline & $\boldsymbol{\alpha}-\mathbf{T}$ & $\boldsymbol{\alpha}-\mathbf{T 3}$ & $\boldsymbol{\beta}-\mathbf{T}$ & $\boldsymbol{\gamma}-\mathbf{T}$ & $\mathbf{P - 8}$ & $\boldsymbol{\gamma}$-T3 & $\boldsymbol{\delta}$-T \\
\hline Linseed & 0.8 & n.d. & n.d. & 39.0 & 13.5 & n.d. & 0.5 \\
Apricot (Sweet) & 2.8 & n.d. & n.d. & 67.3 & n.d. & n.d. & 2.2 \\
Apricot (Bitter) & 3.1 & n.d. & n.d. & 81.0 & n.d. & n.d. & 2.5 \\
Pear (Ankara) & 5.4 & n.d. & 0.2 & 55.6 & 0.6 & n.d. & 1.3 \\
Fennel (Dulce) & n.d. & 1.4 & n.d. & 0.5 & n.d. & 18.2 & n.d. \\
Peanut & 14.9 & n.d. & 0.5 & 16.9 & n.d. & 0.5 & 0.7 \\
Apple (Golden) & 51.4 & n.d. & 28.3 & 6.8 & n.d. & n.d. & 3.5 \\
Apple (Starking) & 54.4 & n.d. & 30.9 & 0.5 & n.d. & n.d. & 1.7 \\
Cotton & 36.2 & 0.3 & 0.2 & 48.7 & 1.1 & n.d. & 0.3 \\
Quince & 49.6 & 3.2 & 27.8 & 8.2 & n.d. & n.d. & 5.2 \\
Chufa & 68.5 & n.d. & 1.4 & 0.5 & 0.3 & n.d. & n.d. \\
Apple (Starking) & 60.5 & 0.3 & 34.3 & n.d. & n.d. & n.d. & n.d. \\
\hline
\end{tabular}

n.d., not detectable; T, tocopherol; T3, tocotrienol; P-8, Plastochromanol-8.

All the oils investigated exhibited differences in their tocopherol contents. The predominant tocopherol compounds in the different seeds oils were $\alpha$ - and $\gamma$-tocopherol. Additionally in some oils lower amounts of $\alpha$-tocotrienol, $\beta$-tocopherol, plastochromanol- 8 and $\delta$-tocopherol were found. The main vitamin-E-active compound of fennel seed oil was $\gamma$-tocotrienol with $18.2 \mathrm{mg} / 100 \mathrm{~g}$. Also seed oils of other members of the family Apiaceae are characterized by a higher content of tocotrienols, such as dill (Anethum graveolens) (10.2 mg/100 g $\alpha$-tocotrienol) or coriander (Coriandrum sativum L.) (23.1 mg/100 g $\gamma$-tocotrienol) [33].

The $\alpha$-tocopherol group comprised of apple (golden) $(51.4 \mathrm{mg} / 100 \mathrm{~g})$, apple (starking) $(54.4 \mathrm{mg} / 100 \mathrm{~g}$, $60.5 \mathrm{mg} / 100 \mathrm{~g})$, quince $(49.6 \mathrm{mg} / 100 \mathrm{~g})$ and chufa $(68.5 \mathrm{mg} / 100 \mathrm{~g})$ seed oil. Except for chufa seed oil, these oils also contained higher amounts of $\beta$-tocopherol with an average amount of about $30 \mathrm{mg} / 100 \mathrm{~g}$ ranging between 27.8 (quince seed oil) and $34.3 \mathrm{mg} / 100 \mathrm{~g}$ (apple seed oil (starking)). $\gamma$-tocopherol was predominant in linseed oil (39.0 mg/100 g), apricot seed oil (sweet, $67.3 \mathrm{mg} / 100 \mathrm{~g}$ ), apricot seed oil (bitter, $81.1 \mathrm{mg} / 100 \mathrm{~g})$, pear seed oil (55.6 mg/100 g), and cottonseed oil (48.7 mg/100 g).Among theseed oils in this group only cottonseed oil contained considerably high amount of $\alpha$-tocopherol $(36.2 \mathrm{mg} / 100 \mathrm{~g})$ while for the other seed oils $\gamma$-tocopherol accounted for between $72 \%$ and $93 \%$ of the total vitamin-E-active compounds. In linseed oil remarkable amounts of plastochromanol-8 were found $(13.5 \mathrm{mg} / 100 \mathrm{~g})$. 
Peanut oil neither belongs to the $\alpha$-tocopherol nor to the $\gamma$-tocopherol group. The oil showed the lowest total amount of vitamin-E-active compounds of all investigated oils with almost equal amounts of $\alpha$-tocopherol $(14.9 \mathrm{mg} / 100 \mathrm{~g})$ and $\gamma$-tocopherol $(16.9 \mathrm{mg} / 100 \mathrm{~g})$.

\section{Conclusions}

Linseeds, apricot seeds, pear seeds and peanut seeds contained more than $30 \mathrm{~g} / 100 \mathrm{~g}$ oil making them interesting as valuable sources for oil production. Due to the lower oil content the other seeds can be interesting for oil processing if the raw material also contains protein with valuable amino acid composition, such as soybeans. The value of the oil depends on the fatty acid composition and the composition of vitamin-E-active compounds. Here the oils can be divided into two groups, one predominant in oleic acid with contents higher than $50 \mathrm{~g} / 100 \mathrm{~g}$ (apricot seed oil, peanut oil, chufa seed oil) and one group mainly comprised of linoleic acid (pear seed oil, apple seed oil, cottonseed oil and quince seed oil). Linseed oil is characterized by a high amount of $\alpha$-linolenic acid and fennel seed oil contained higher amounts of 18:1 fatty acids with petroselinic acid as predominant fatty acid which is usable in technical applications. Especially the fatty acid composition of apricot seed oil with low amount of saturated fatty acids, high amounts of oleic acid and moderate amounts of polyunsaturated fatty acids seems to be an interesting sources as edible oils for human nutrition. The composition of vitamin-E-active compounds of the different oils is characterized by either high amounts of $\alpha$-tocopherol together with moderate amounts of $\beta$-tocopherol or by high amounts of $\gamma$-tocopherol. The predominant vitamin-E-amount in fennel seed oil is $\gamma$-tocotrienol and peanut oil contains more or less equal amounts of $\alpha$ - and $\gamma$-tocopherol. High sources of vitamin-E-active compounds with more than $70 \mathrm{mg} / 100 \mathrm{~g}$ are apricot seed oil, apple seed oil, cottonseed oil and quince seed oil.

In summary it can be concluded that raw materials such as seeds from fruit and vegetable processing are interesting and valuable sources for the production of vegetable oils usable as suppliers of fatty acids and vitamin-E-active compounds in human nutrition or technical applications.

\section{Acknowledgments}

This work was supported by The Scientific and Technical Research of Turkey (TÜBITAK) and Deutsche Forschungsgemeinschaft (DFG, Germany). The authors also thank to C.E., U.E. and B.B. for skilful technical assistance with gas liquid chromatography and high performance liquid chromatography.

\section{Author Contributions}

The experimental design was conceived and designed by M. M. Özcan and B. Matthäus. M. M. Özcan was responsible for the choice, collection, drying and purification of the samples. B. Matthäus carried out the analysis of the samples regarding oil content as well as composition of fatty acids and vitamin-E-active compounds. M. M. Özcan contributed the sections on introduction, methods and parts of the results, while B. Matthäus wrote the results and conclusions. 


\section{Conflicts of Interest}

The authors declare no conflict of interest.

\section{References}

1. Femenia, A.; Rossello, C.; Mulet, A.; Canellas, J. Chemical composition of bitter and sweet apricot kernels. J. Agric. Food Chem. 1995, 43, 356-361.

2. Kamel, B.S.; Kakuda, Y. Characterization of the seed oil and meal from apricot, cherry, nectarine, peach and plum. J. Am. Oil Chem. Soc. 1992, 69, 492-494.

3. Nehdi, I.A. Characteristics and composition of Washingtonia filifera (Linden ex André) H Wendl. seed and seed oil. Food Chem. 2011, 126, 197-202.

4. Nehdi, I.A. Characteristics, chemical composition and utilisation of Albizia julibrissin seed oil. Ind. Crops Prod. 2011, 33, 30-34.

5. Nogala-Kalucka, M.; Rudzinska, M.; Zadernowski, R.; Siger, A.; Krzyzostaniak, I. Phytochemical content and antioxidant properties of seeds of unconventional oil plants. J. Am. Oil Chem. Soc. 2010, 87, 1481-1487.

6. Abdel-Rahaman, A.-H.Y. A study on some Egyptian citrus seed oils. Grasas Aceit. 1980, 31, 331-333.

7. Oilseeds-Determination of Hexane Extract (or Light Petroleum Extract), Called "Oil Content"; International Standard ISO 659:1998; ISO: Geneva, Switzerland, 1998.

8. Animal and Vegetable Fats and Oils-Preparation of Methyl Esters of Fatty Acids; International Standard ISO 5509:2000; ISO: Geneva, Switzerland, 2000.

9. Balz, M.; Schulte, E.; Thier, H.-P. Trennung von Tocopherolen und Tocotrienolen durch HPLC. Eur. J. Lipid Sci. Technol. 1992, 94, 209-213.

10. Teneva, O.T.; Zlatanov, M.D.; Antova, G.A. Lipid composition of flaxseeds. Bulg. Chem. Comm. 2014, 36, 157-163.

11. Dubois, V.; Breton, S.; Linder, M.; Fani, J.L.; Parmentier, M. Fatty acid profiles of 80 vegetable oils with regard to their nutritional potential. Eur. J. Lipid Sci. Technol. 2007, 109, 710-732.

12. Kim, M.; No, S.; Yoon, S.H. Stereospecific analysis of fatty acid composition of chufa (Cyperus esculentus L.) tuber oil. J. Am. Oil Chem. Soc. 2007, 84, 1079-1080.

13. Eteshola, E.; Oraedu, A.C.I. Fatty acid compositions of tiger nut tubers (Cyperus esculentus L.) baobab (Adansonia digitata L.) and their mixture. J. Am. Oil Chem. Soc. 1996, 73, 255-257.

14. Reiter, B.; Lechner, M.; Lorbeer, E. The fatty acid profiles — including petroselinic and cis-vaccenic acid—of different Umbelliferae seed oils. Lipid Fett 1998, 100, 498-502.

15. Kostik, V.; Memeti, S.; Bauer, B. Fatty acid composition of edible oils and fats. J. Hyg. Eng. Des. 2013, 4, 112-116.

16. Seher, V.A.; Gundlach, U. Isomere monoensauren in Pflanzenölen. Fette Seifen Anstrichm. 1982, 84, 342-349.

17. Dambroth, V.M.; Kluding, H.; Seehuber, R. Vegetable oils as raw materials of industry-A contribution of agriculture to secure the raw materials. Fette Seifen Anstrichm. 1982, 84, 173-178. 
18. Overeem, A.; Buisman, G.J.H.; Derksen, J.T.P.; Cuperus, F.P.; Molhoek, L.; Grisnich, W.; Goemans, C. Seed oils rich in linolenic acid as renewable feedstock for environment-friendly in powder coatings. Ind. Crops Prod. 1999, 10, 157-165.

19. Ryan, E.; Galvin, K.; O’Connor, T.P.; Maguire, A.R. Phytosterol, squalene, tocopherol content and fatty acid profile of selected seeds, rains, and legumes. Plant Foods Hum. Nutr. 2007, 62, 85-91.

20. Wu, J.; Gao, H.; Zhao, L.; Liao, X.; Chen, F.; Wang, Z.; Hu, X. Chemical compositional characterization of some apple cultivars. Food Chem. 2007, 103, 88-93.

21. Yazıcıoğlu, T.; Karaali, A. On the fatty acid composition of Turkish vegetable oils. Fette Seifen Anstrichm. 1983, 85, 23-29.

22. Beringer, H.; Dompert, W.U. Fatty acid and tocopherol pattern in oil seeds. Fette Seifen Anstrichm. 1976, 78, 228-231.

23. Kamal-Eldin, A.; Andersson, R.A. A multivariate study of the correlation between tocopherol content and fatty acid compostion in vegetable oils. J. Am. Oil Chem. Soc. 1997, 74, 375-380.

24. Stephens, N.G.; Parsons, A.; Schofield, P.M.; Kelly, F.; Cheeseman, K.; Mitchinson, M.J. Randomised controlled trial of vitamin $\mathrm{E}$ in patients with coronary disease: Cambridge Heart Antioxidant Study (CHAOS). Lancet 1996, 347, 781-786.

25. Jiang, Q.; Elson-Schwab, I.; Courtemanche, C.; Ames, B.N. $\gamma$-tocopherol and its major metabolite, in contrast to $\alpha$-tocopherol, inhibit cyclooxygenase activity in macrophages and epithelial cells. Proc. Natl. Acad. Sci. 2000, 97, 11494-11499.

26. Jiang, Q.; Lykkesfeldt, J.; Shigenaga, M.K.; Shigeno, E.T.; Christen, S.; Ames, B.N. $\gamma$-tocopherol supplementation inhibits protein nitration and ascorbate oxidation in rats with inflammation. Free Radic. Biol. Med. 2002, 33, 1534-1542.

27. Hensley, K.; Benaksas, E.J.; Bolli, R.; Comp, P.; Grammas, P.; Hamdheydari, L.; Mou, S.; Pye, Q.N.; Stoddard, M.F.; Wallis, G.; et al. New perspectives on vitamin E: $\gamma$-tocopherol and carboxyethylhydroxylchroman metabolites in biology and medicine. Free Rad. Bio. Med. 2004, 36, $1-15$.

28. Olejnik, D.; Gogolewski, M.; Nogala-Kalucka, M. Isolation and some properties of plastochromanol-8. Nahrung 1997, 41, 101-104.

29. Pongracz, G.; Weiser, H.; Matzinger, D. Tocopherole_-Antioxidantien der natur. Fat Sci. Technol. 1995, 97, 90-104.

30. Papas, A.M. Oil-soluble antioxidants in foods. Toxicol. Ind. Health 1993, 9, 123-149.

31. Elmadfa, I.; Wagner, K.-H. Vitamin E und Haltbarkeit von Pflanzenölen. Fett Lipid 1997, 99, 234-238.

32. AOCS. Official Methods and Recommended Practices of the American Oil Chemists' Society: Physical and Chemical Characteristics of Oils, Fats and Waxes; AOCS Press: Champaign, IL, USA, 1996.

33. Matthäus, B.; Vosmann, K.; Long Quoc, P.; Aitzetmüller, K. FA and tocopherol composition of Vietnamese oilseeds. J. Am. Oil Chem. Soc. 2003, 80, 1013-1020.

(C) 2015 by the authors; licensee MDPI, Basel, Switzerland. This article is an open access article distributed under the terms and conditions of the Creative Commons Attribution license (http://creativecommons.org/licenses/by/4.0/). 